\title{
Electrophoretic Component of Electric Pulses Determines the Efficacy of In Vivo DNA Electrotransfer
}

\author{
SAULIUS S̆ATKAUSKAS, ${ }^{1,2}$ FRANCK ANDRÉ,${ }^{1}$ MICHEL F. BUREAU,${ }^{3}$ DANIEL SCHERMAN,${ }^{3}$ \\ DAMIJAN MIKLAVČIC ${ }^{4}$ and LLUIS M. MIR ${ }^{1}$
}

\begin{abstract}
Efficient DNA electrotransfer can be achieved with combinations of short high-voltage (HV) and long lowvoltage (LV) pulses that cover two effects of the pulses, namely, target cell electropermeabilization and DNA electrophoresis within the tissue. Because $\mathrm{HV}$ and $\mathrm{LV}$ can be delivered with a lag up to 3000 sec between them, we considered that it was possible to analyze separately the respective importance of the two types of effects of the electric fields on DNA electrotransfer efficiency. The tibialis cranialis muscles of C57BL/6 mice were injected with plasmid DNA encoding luciferase or green fluorescent protein and then exposed to various combinations of $\mathrm{HV}$ and $\mathrm{LV}$ pulses. DNA electrotransfer efficacy was determined by measuring luciferase activity in the treated muscles. We found that for effective DNA electrotransfer into skeletal muscles the HV pulse is prerequisite; however, its number and duration do not significantly affect electrotransfer efficacy. DNA electrotransfer efficacy is dependent mainly on the parameters of the $L V$ pulse(s). We report that different $L V$ number, $L V$ individual duration, and $L V$ strength can be used, provided the total duration and field strength result in convenient electrophoretic transport of DNA toward and/or across a permeabilized membrane.
\end{abstract}

\section{INTRODUCTION}

$\mathbf{E}$ LECTRICALLY MEDIATED GENE TRANSFER, also termed DNA electrotransfer or electrogene therapy, has gained real interest as it is one of the most effective methods of in vivo nonviral gene transfer (André and Mir, 2004). The method has been shown to be effective in electrotransferring plasmid DNA to various tissues: muscles (Aihara and Miyazaki, 1998; Mir et al., 1998a, 1999), liver (Heller et al., 1996; Suzuki et al., 1998), skin (Titomirov et al., 1991; Zhang et al., 1996), tumors (Heller et al., 2000; Wells et al., 2000; Heller and Coppola, 2002), mouse testis (Muramatsu et al., 1997, 1998), and so on (André and Mir, 2004).

The mechanisms by which electric pulses mediate DNA transfer into target cells are not well understood. Nevertheless, there is common agreement that for improved DNA transfer into tissue, cells in that tissue must be permeabilized. Such permeabilization can be achieved using simple runs of short square-wave electric pulses (in the range of $100 \mu \mathrm{sec}$ ) (Mir et al., 1991b; Gehl et al., 1999; Miklavčič et al., 2000). This kind of pulse has been widely used for the local delivery of nonpermeant anticancer drugs (such as bleomycin or cisplatin) in a form of treatment termed "antitumor electrochemotherapy" (Mir et al., 1991a, 1998b; Glass et al., 1997; Sersa et al., 1998; Rodriguez et al., 2002). Indeed, the delivery to tumors of, for example, eight pulses of $1300 \mathrm{~V} / \mathrm{cm}$ and $100 \mu \mathrm{sec}$ either in vitro or in vivo is sufficient to induce transient rearrangements of the cell membrane that allow nonpermeant anticancer molecules such as bleomycin to enter the cell by diffusion and to fully exert their cytotoxic activity (Mir et al., 1991b; Poddevin et al., 1991; Gehl et al., 1998).

These short permeabilizing electric pulses have also been shown to increase the transfer of plasmid DNA into several tissue types (Heller et al., 1996, 2000). However, another type of square-wave electric pulse was applied to muscles (Aihara and Miyazaki, 1998; Mir et al., 1999), tumors (Rols et al., 1998), liver (Suzuki et al., 1998), and some other tissues (André and Mir, 2004), and was found to be more effective for DNA electrotransfer (Mir et al., 1999; Heller et al., 2000). These pulses usually are of lower voltage but much longer duration (in the

\footnotetext{
${ }^{1}$ Vectorology and Gene Transfer, UMR 8121 CNRS, Institute Gustave Roussy, F-94805 Villejuif, France.

${ }^{2}$ Department of Biology, Vytautas Magnus University, LT-44404 Kaunas, Lithuania.

${ }^{3}$ U 266 INSERM-FRE 2463 CNRS, Faculté de Pharmacie, Université Paris 5, F-75270 Paris, France.

${ }^{4}$ Faculty of Electrical Engineering, University of Ljubljana, SI-1000 Ljubljana, Slovenia.
} 
range of tens of milliseconds) (Aihara and Miyazaki, 1998; Rols et al., 1998; Mir et al., 1999; Bettan et al., 2000; Matsumoto et al., 2001). It is assumed that this type of pulse mediates DNA transfer into cells by inducing two distinct effects that include cell permeabilization (like the short pulses) and DNA electrophoretic migration during the delivery of the electric field (Klenchin et al., 1991; Sukharev et al., 1992; Neumann et al., 1996; Mir et al., 1999; Golzio et al., 2002). The double role of the electric pulses in in vivo DNA electrotransfer was demonstrated by using combinations of electric pulses consisting of high-voltage, short pulses (or HVs; e.g., $800 \mathrm{~V} / \mathrm{cm}$ and 100 $\mu \mathrm{sec}$ ) followed by low-voltage, long pulses (or LVs; e.g., 80 $\mathrm{V} / \mathrm{cm}$ and $100 \mathrm{msec}$ ) (Bureau et al., 2000; S̆atkauskas et al., 2002). In a previous study we found that these HV and LV pulses can be separated by various lag times between the HV and LV pulses without significant loss in transfection efficiency. These lag times ranged up to $300 \mathrm{sec}$ for a combination of one HV and one LV, and up to $3000 \mathrm{sec}$ for a combination of one HV and four LV (Šatkauskas et al., 2002).

Taking into account these lag times between the HV and LV pulses, we thought it possible to characterize separately the respective importance of the two effects of the electric fieldselectropermeabilization and electrophoresis-on DNA electrotransfer efficacy.

\section{MATERIALS AND METHODS}

\section{Plasmid DNA}

We used plasmid pXL3031 (pCMV-Luc+) containing the cytomegalovirus promoter (nucleotides 229-890 of pcDNA3; Invitrogen, Carlsbad, CA) inserted upstream of the sequence for $l u c$, encoding a modified cytosolic wild-type firefly luciferase (Soubrier et al., 1999). We prepared plasmid DNA according to the usual procedures (Ausubel et al., 1994). Alternatively, we also used plasmid pEGFP-N1 (BD Biosciences Clontech, Saint Quentin Yvelines, France), featuring the gene encoding green fluorescent protein (GFP) under the control of the CMV promoter and prepared in phosphate-buffered saline (PBS; GIBCO/Invitrogen, Cergy-Pontoise, France) with an EndoFree Plasmid Giga kit (Qiagen, Courtabeuf, France).

\section{Animals}

For all experimental procedures we anesthetized female, 7to 9-week-old C57BL/6 mice by intraperitoneal administration of the anesthetics ketamine (Ketalar, $100 \mathrm{mg} / \mathrm{kg}$; Panpharma, Fougères, France) and xylazine (Rompun, $40 \mathrm{mg} / \mathrm{kg}$; Bayer, Puteaux, France). Before performing the experiments subject legs were shaved with an electric shaver. At least 10 muscles (5 mice) were included in each experimental group for luciferase determinations. In the case of the GFP qualitative data, four muscles were used for each experimental condition.

\section{DNA injection}

For the luciferase experiments, we injected $3 \mu \mathrm{g}$ of plasmid DNA prepared in $30 \mu \mathrm{l}$ of $0.9 \% \mathrm{NaCl}$. In most of our experiments (see Figs. 1-3) we supplemented the DNA solution with heparin (120 IU/ml; Laboratoires Leo, Saint Quentin en Yvelines, France;
$1 \mathrm{mg}$ of the heparin [MW 10,000-12,000] corresponded to approximately $137 \mathrm{IU})$. We injected the DNA into tibialis cranialis muscles, using a Hamilton syringe with a 26-gauge needle. Because the quality of injection of the plasmid may affect transfection efficacy, all injections within a given experiment were performed by the same well-trained investigator. For GFP experiments, $4 \mu \mathrm{g}$ in $20 \mu \mathrm{l}$ of PBS was injected into each treated tibialis cranialis muscle, always in the absence of heparin.

\section{DNA electrotransfer}

$\mathrm{HV}$ and LV pulse combinations were generated by a device consisting of square-wave electropulsator (PS-15; Jouan, St. Herblain, France) and a microprocessor-driven switch/function generator built at the Faculty of Electrical Engineering at the University of Ljubljana (Ljubljana, Slovenia). The device allowed for precise control of every electrical parameter of HV and LV pulse combinations (S̆atkauskas et al., 2002).

$\mathrm{HV}$ and LV pulse combinations were delivered soon (40 \pm $15 \mathrm{sec}$ ) after intramuscular DNA injection. In all the experiments we fixed the lag between HV and LV to $1 \mathrm{sec}$. For pulse delivery to the muscles we used stainless plate electrodes 4.4 $\mathrm{mm}$ apart. The 1-cm plates encompassed the whole leg of each mouse. To ensure good contact between the tibialis cranialis muscle of the exposed leg and the plates of the electrodes a conductive gel was used. Electric field values (in volts per centimeter) are always expressed in terms of the ratio of the voltage applied (volts) to the distance between the electrodes (centimeters).

For the GFP experiments the pulse combinations were delivered with a Cliniporator (IGEA, Carpi, Modena, Italy) generator and electrodes ( $5 \mathrm{~mm}$ apart) from the same company.

\section{Luciferase activity measurement}

We killed the mice 2 days after DNA electrotransfer. We removed and homogenized the muscles (net weight, approximately $60 \mathrm{mg}$ ) in $1 \mathrm{ml}$ of cell culture lysis reagent solution (10 $\mathrm{ml}$ of cell culture lysis reagent; Promega, Charbonnières, France), diluted with $40 \mathrm{ml}$ of distilled water and supplemented with one protease inhibitor cocktail tablet (Roche, Mannheim, Germany). After centrifugation at $12,000 \mathrm{rpm}$ for $10 \mathrm{~min}$ at $4^{\circ} \mathrm{C}$, we assessed the luciferase activity in $10 \mu \mathrm{l}$ of the supernatant, using a Wallac Victor ${ }^{2}$ luminometer (PerkinElmer Life and Analytical Sciences, Boston, MA), by integration of the light produced over $1 \mathrm{sec}$, starting after the addition of $50 \mu \mathrm{l}$ of luciferase assay substrate (Promega) to the muscle lysate. We collected the results from the luminometer in relative light units (RLU). Calibration with purified firefly luciferase protein showed that $10^{6} \mathrm{RLU}$ corresponds to approximately $70 \mathrm{ng}$ of expressed luciferase. We expressed the final results as picograms of luciferase per muscle.

\section{GFP fluorescence observations}

We killed the mice 3 days after the injection of pEGFP-N1 plasmid and observed the transfected tissue with an MZ12 fluorescence stereomicroscope with a GFP Plus filter set (excitation filter, 480/40 nm; dichroic mirror, $505 \mathrm{~nm}$ LP; barrier filter, $510 \mathrm{~nm} \mathrm{LP)} \mathrm{(Leica,} \mathrm{Rueil-Malmaison,} \mathrm{France).} \mathrm{After}$ removal of the leg skin, pictures were taken with a digital cooled 
color camera (AxioCam HRc; Zeiss, Le Pecq, France), and quantification of GFP expression was made by software (AxioVision Light Edition, release 4.1.1.0; Zeiss) integration of the light detected by the camera. Pictures were taken either at a constant exposure time $(100 \mathrm{msec})$ or at a variable exposure time, that is, allowing the camera to adjust the exposure time to acquire an equivalent amount of light from picture to picture. Each experimental condition was repeated four times (four muscles treated). Quantitative analysis was done by determining the mean density of the green color in these images, using a relative scale with 256 levels of intensity.

\section{Statistical analysis}

For statistical comparison of several groups we used the twotailed Student $t$ test for unpaired values. In the figures we reported luciferase expression data as means \pm SD.

\section{RESULTS}

In the luciferase experiments, because of the high sensitivity of the measurements, we injected a solution of plasmid DNA supplemented with low amounts of heparin (120 IU/ml). Heparin at this dose causes a large decrease in the spontaneous uptake of DNA by the muscle but does not significantly impair the efficacy of DNA electrotransfer into the muscle fibers (Şatkauskas et al., 2001). Therefore, the respective contributions of HV and LV pulses to the efficiency of DNA electrotransfer can be analyzed more precisely in the presence of heparin. In addition, we fixed the lag time between HV and LV pulse(s) to $1 \mathrm{sec}$.

\section{Influence of $H V$ pulse duration and number}

To analyze the role of the electropermeabilizing (HV) pulses we used LV pulses giving the best level of gene expression according to previous data (S̆atkauskas et al., 2002). Therefore we fixed the LV component parameters to four LVs of $80 \mathrm{~V} / \mathrm{cm}$ and 100-msec duration, with a delay between pulses of $1 \mathrm{sec}$.

We tried to improve muscle permeabilization by increasing either the number (from one to eight) or the duration (from 100 to $500 \mu \mathrm{sec}$ ) of the HV pulses. As shown in Fig. 1, neither an increase in HV duration, nor an increase in HV pulse number, significantly enhanced muscle transfection.

\section{Influence of $L V$ pulse number}

As a consequence of the results shown in Fig. 1, we always used a single $\mathrm{HV}$ pulse of $800 \mathrm{~V} / \mathrm{cm}$ and $100 \mu \mathrm{sec}$ to analyze the role of the LV component. First, we examined the influence of the number of LVs. We fixed LV pulse strength at $80 \mathrm{~V} / \mathrm{cm}$, with a duration of $100 \mathrm{msec}$, and the delay between LVs at 1 sec. Luciferase expression markedly increased when we increased LV number from one to four (Fig. 2A). Consistent with previous data (S̆atkauskas et al., 2002), with four LVs the luciferase expression was 10 times higher than with one LV. No further significant increase was observed with a larger number (six or eight) of LV pulses (Fig. 2A).

Subsequent experiments on the influence of pulse number on gene transfer efficacy were performed with 50-msec LV(s) (Fig. 2B). We observed the same trend as in the case of 100-msec

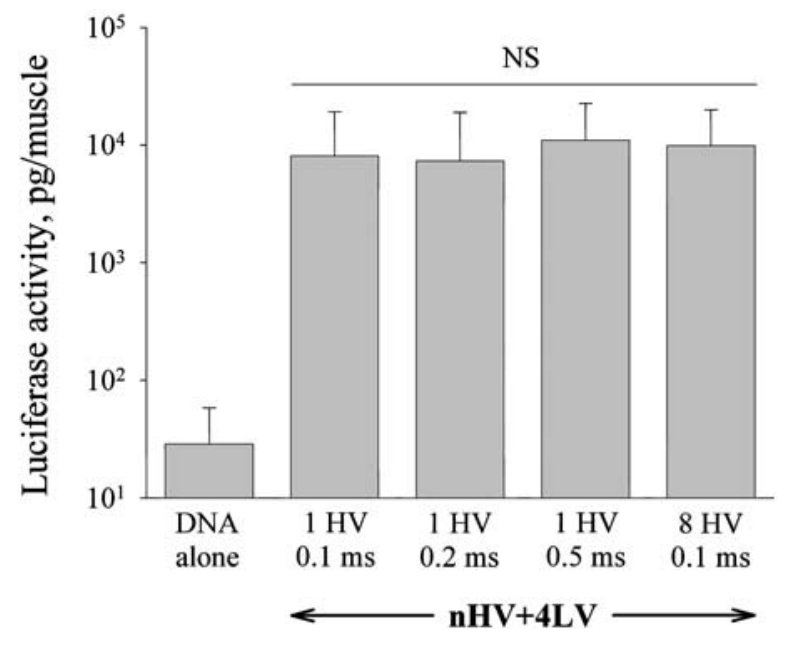

FIG. 1. Luciferase expression after DNA electrotransfer based on combinations of one or eight HV pulses $(800 \mathrm{~V} / \mathrm{cm}$; $0.1,0.2$, or $0.5 \mathrm{msec}$ ) and four LV pulses $(80 \mathrm{~V} / \mathrm{cm}$ and 100 $\mathrm{msec})(n \mathrm{HV}+4 \mathrm{LV}$ pulse combination). Data are presented as means \pm SD. The significance of differences between each of the $n \mathrm{HV}+4 \mathrm{LV}$ groups was calculated by $t$ tests; NS, not significant. Each column represents results from at least 18 muscles treated in two experiments.

LV(s) (Fig. 2A). In both cases the beginning of the plateau in luciferase gene expression started at a total pulse duration of 400 msec. Again, no further significant increase was observed with increased number (12 or 16) of LV pulses. These data also suggested that similar levels of DNA electrotransfer and gene expression may be achieved with different combinations of LV pulse number and duration. To test this hypothesis, we used four different combinations of number $(n)$ and duration $(d)$ of LVs, such that the product $n \times d$ was constant and equal to $400 \mathrm{msec}$ (Fig. 2C). A tendency to a progressive decrease in luciferase gene expression with the concomitant decrease in individual pulse duration and increase in pulse number was found (Fig. 2C). For instance, $\mathrm{HV}$ and LV combinations using one LV of $400 \mathrm{msec}$ resulted in about two times higher luciferase gene expression compared with eight LVs of $50 \mathrm{msec}(p<0.001)$.

\section{Influence of $L V$ pulse strength}

Figure 3 shows the dependence of DNA electrotransfer and expression on the electric field strength of the LV pulses. We examined LV pulse strengths ranging from 20 to $100 \mathrm{~V} / \mathrm{cm}$. At low electric field strengths (20 and $40 \mathrm{~V} / \mathrm{cm})$, luciferase expression was not significantly increased $(p>0.05)$ in comparison with that achieved with the HV pulse alone. At $60 \mathrm{~V} / \mathrm{cm}$ LV pulses started to play a significant role and luciferase expression was already more than 100 times higher than that obtained by HV pulse alone. We obtained the highest values of luciferase expression with LVs of $100 \mathrm{~V} / \mathrm{cm}$ (Fig. 3).

\section{Combination of $L V$ pulse strength and duration}

In this set of experiments, we aimed to analyze whether the decrease in efficacy when using LVs of lower field strength 

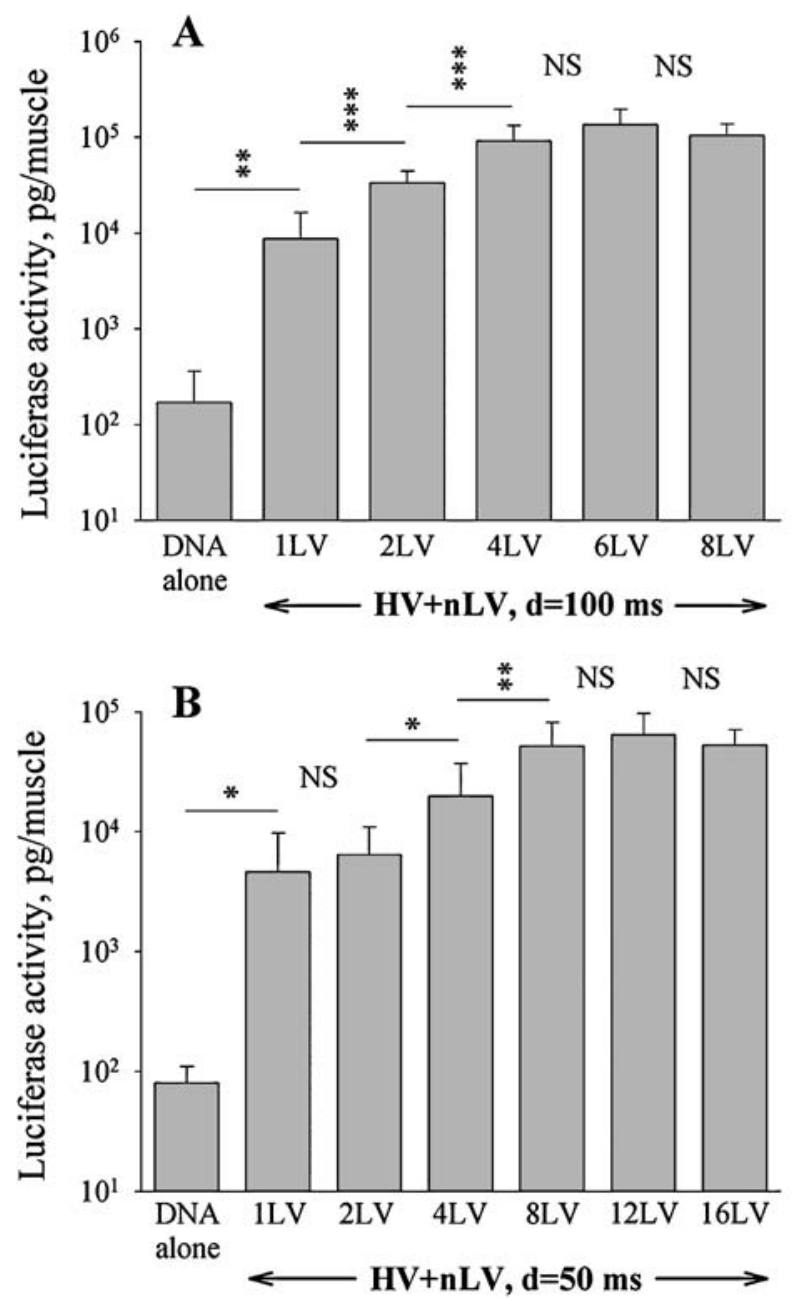

(e.g., $60 \mathrm{~V} / \mathrm{cm}$, as in Fig. 3) could be counterbalanced by the use of longer pulses. We thus compared several combinations of one HV and four LVs, using LVs of either 60 or $80 \mathrm{~V} / \mathrm{cm}$ and individual pulse durations between 100 and $800 \mathrm{msec}$ (Fig. 4).

With one HV and four LVs at a pulse strength of $80 \mathrm{~V} / \mathrm{cm}$ we obtained similar luciferase expression at the three LV pulse durations tested (100, 200, and $400 \mathrm{msec}$ ) (Fig. 4). With one $\mathrm{HV}$ and four LVs at a pulse strength of $60 \mathrm{~V} / \mathrm{cm}$ and a pulse duration of $400 \mathrm{msec}$ we obtained a result similar to those achieved under the previously tested conditions at $80 \mathrm{~V} / \mathrm{cm}$, whereas at a longer pulse duration $(800 \mathrm{msec})$, luciferase expression was significantly higher with respect to the $80-\mathrm{V} / \mathrm{cm}$, 100-msec pulses (Fig. 4).

\section{GFP fluorescence observations}

The distribution and intensity of the fluorescence within muscles after electrotransfer of the GFP gene were qualitatively and semiquantitatively measured with a fluorescence stereo microscope (Fig. 5). For the electrotransfer of the GFP gene we used one HV of $100 \mu \mathrm{sec}$ and $800 \mathrm{~V} / \mathrm{cm}$ followed after a 1-sec delay by one $400-\mathrm{msec} \mathrm{LV}$ pulse of either 60,80 , or $100 \mathrm{~V} / \mathrm{cm}$. Pictures were taken either at a constant exposure time (100 msec; Fig. 5A-C) or

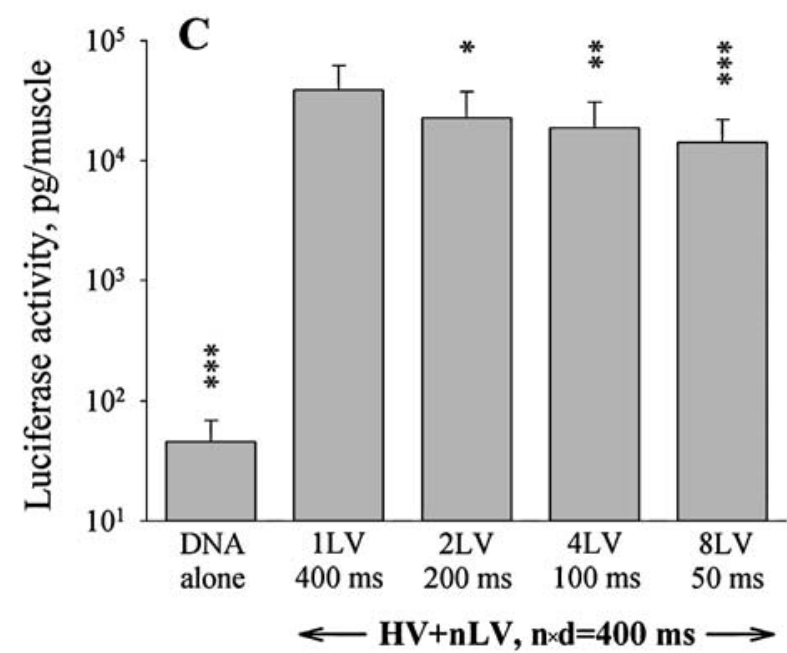

FIG. 2. Luciferase expression after DNA electrotransfer based on a combination of one $\mathrm{HV}$ pulse $(800 \mathrm{~V} / \mathrm{cm}$ and 100 ìsec) and a various number of LV pulses $(80 \mathrm{~V} / \mathrm{cm}$ and 100 $\mathrm{msec})(\mathrm{HV}+n \mathrm{LV}$ pulse combinations): (A) using various numbers ( $n$ ) of LV pulses, each with a duration $d$ of $100 \mathrm{msec}$; (B) using various numbers $(n)$ of LV pulses, each with a duration $d$ of $50 \mathrm{msec}$; $(\mathbf{C})$ using various numbers $(n)$ of LV pulses of various durations $d$ such that the product $n \times d$ is constant and equal to $400 \mathrm{msec}$. Data are presented as means $\pm \mathrm{SD}$. The significance of differences between neighboring groups was calculated by $t$ tests and is indicated by asterisks $\left({ }^{*} p<0.05\right.$; ** $p<$ $0.01 ; * * * p<0.001$; NS, not significant). Each column represents results from 10 muscles treated during one experiment (A and $\mathbf{B}$ ) or from at least 16 muscles treated in two experiments (C).

at a variable exposure time, that is, allowing the camera to adjust the exposure time to acquire an equivalent amount of light from picture to picture (Fig. 5D-F). These pictures represent the images observed in four muscles for each experimental condition. Two series of pictures are reported to show the reproducibility of the results as well as the large increase in fluorescence with the increase in field strength of the LV pulses (Fig. 5A-C). Quantitative analysis of the mean density of the green color in these images sustains the qualitative data: at a relative scale with 256 levels of intensity, levels 41 (left muscle) and 33 (right muscle) were reached at $60 \mathrm{~V} / \mathrm{cm}$ (Fig. 5A), whereas levels 111 and 89 were reached at $80 \mathrm{~V} / \mathrm{cm}$ (Fig. 5B) and levels 138 and 127 were reached at 100 $\mathrm{V} / \mathrm{cm}$ (Fig. 5C). These pictures also show that the volume of transfected (fluorescent) muscle is similar whatever the LV field strength (Fig. 5D-F). These data suggest that the overall increase in fluorescence results from an increase in the fluorescence of each fiber, and not from an increase in the volume (and thus the number) of muscle fibers susceptible to fluorescence.

\section{DISCUSSION}

Using combinations of $\mathrm{HV}$ and $\mathrm{LV}$ pulses, we previously showed that in vivo DNA electrotransfer is a multistep process 


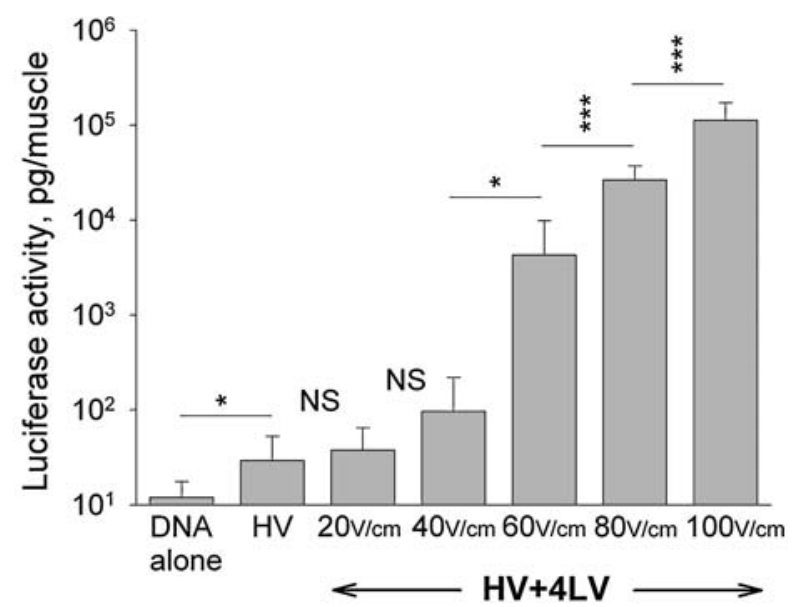

FIG. 3. Luciferase expression after DNA electrotransfer based on a combination of one HV pulse $(800 \mathrm{~V} / \mathrm{cm}$ and 100 $\mu \mathrm{sec}$ ) and four 100-msec LV pulses as a function of the strength of the LV pulses. Data are presented as means \pm SD. The significance of differences between neighboring groups was calculated by $t$ tests and is indicated by asterisks $\left({ }^{*} p<0.05\right.$; $*_{* *} p<0.001$; NS, not significant). Each column represents results from 10 muscles treated in one experiment.

that includes DNA distribution, cell permeabilization, and DNA electrophoresis (Šatkauskas et al., 2002). We found that the role of the HV pulse was limited mainly to cell permeabilization, whereas LV pulses had a direct effect on DNA, probably DNA electrophoresis. However, the interplay between HV and LV pulses, and how the parameters of HV and LV pulses influenced DNA electrotransfer, were still unclear. In elegant in vitro experiments using 1,2, and 3\% agarose gels and pulses similar to our LV pulses, Zaharoff and Yuan (2004) analyzed DNA electromobility: they showed that, using pulses of 10 to $99 \mathrm{msec}$ at 100 to $400 \mathrm{~V} / \mathrm{cm}$ (comparable to our LV pulses), plasmids were transported over distances longer, by two to three orders of magnitude, than those achieved with pulses of $99 \mu \mathrm{sec}$ at $2.0 \mathrm{kV} / \mathrm{cm}$ (comparable to our HV pulses). We discuss here both old and new data on the influence of HV and LV pulses on DNA electrotransfer efficacy in light of these in vitro data.

It was known that one $100-\mu$ sec $\mathrm{HV}$ pulse alone is not sufficient for efficient DNA electrotransfer (S̆atkauskas et al., 2002); this could be due to insufficient electrophoretic transport of DNA into the tissue. Interestingly, the data reported here show that neither HV pulse duration nor the number of HV pulses had an effect on DNA electrotransfer efficiency. Because eight HVs permeabilize muscle to a significantly greater extent than one HV (Bureau et al., 2000), it seems possible that the achievement of optimal permeabilization by the HV is not critical for effective DNA electrotransfer, at least under the experimental conditions in which LV pulses are optimal or close to optimal (e.g., four LVs at $80 \mathrm{~V} / \mathrm{cm}$ and $100 \mathrm{msec}$ ). Thus muscle must be permeabilized to some extent but not necessarily to the optimal level. This is also supported by our previous studies on the kinetics of membrane resealing after the permeabilization of muscle with one $\mathrm{HV}$ of $800 \mathrm{~V} / \mathrm{cm}$ and $100 \mu \mathrm{sec}$ : even though the level of muscle permeabilization after one $\mathrm{HV}$ pulse significantly decreased after $300 \mathrm{sec}$, high and similar lev- els of DNA electrotransfer and gene expression were still reached with combinations of $\mathrm{HV}$ and LVs in which the four LVs were delivered even $3000 \mathrm{sec}$ after the HV (S̆atkauskas et al., 2002). Nevertheless, HV delivery is prerequisite, because the reverse order of the pulses, that is, an LV plus HV sequence, resulted in levels of DNA expression as low as those obtained by the delivery of one HV pulse alone (S̆atkauskas et al., 2002).

Contrary to the HV pulse, DNA electrotransfer efficacy is highly dependent on the electrical parameters of the LV pulses. For individual LV durations of 100 or $50 \mathrm{msec}$ (Fig. 2A and B), DNA electrotransfer efficacy increased with the number and/or individual duration of the LV pulses until a plateau was reached, when the total duration of the LVs reached $400 \mathrm{msec}$. It is interesting to note that, with respect to total LV pulse duration, patterns of luciferase expression for both individual LV durations were similar (Fig. 2A and B). Because electrophoretic transport (and thus migration distance) in a given medium and at a given voltage depends mainly on the duration of the applied electric field, the results in Fig. 2A and B argue in favor of a true electrophoretic role for the LV pulses. The importance of the electrophoretic effects on DNA electrotransfer efficacy can be explained by the fact that DNA must overcome physical barriers in the interstitial space before achieving close contact with the permeabilized plasma membrane and crossing it. Electrophoretic transport should thus ensure DNA interaction with the permeabilized cell membrane, which explains why the efficiency of DNA electrophoresis governs the efficacy of DNA electrotransfer.

When comparing transfection efficacy levels produced by an identical total duration of LV pulses, but using four different durations for the individual LV pulses, significantly higher levels of gene expression were achieved with the longest individual LV pulses (Fig. 2C). At first glance, this does not seem compatible with the electrophoretic effect of LV pulses suggested previously. However, "compatibility" with a pure electrophoretic effect can

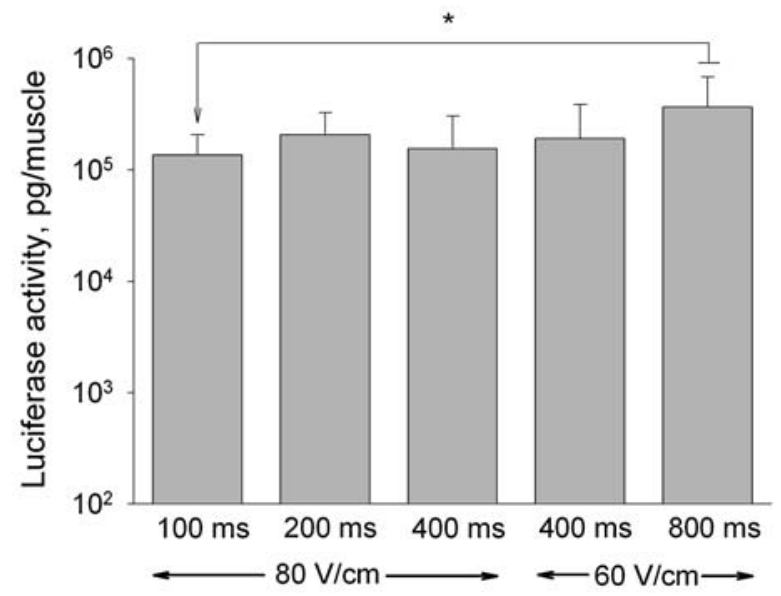

FIG. 4. Luciferase expression after DNA electrotransfer by combinations of one $\mathrm{HV}$ pulse $(800 \mathrm{~V} / \mathrm{cm}, 100 \mu \mathrm{sec})$ and four LV pulses as a function of LV pulse strength and duration. Data are presented as means $\pm \mathrm{SD}$. A statistically significant difference, calculated by $t$ tests, was found only between the 60$\mathrm{V} / \mathrm{cm}, 800$-msec group and the $80-\mathrm{V} / \mathrm{cm}, 100-\mathrm{msec}$ group, and is indicated by an asterisk $(* p<0.05)$. Each column represents results from 10 muscles treated in one experiment. 

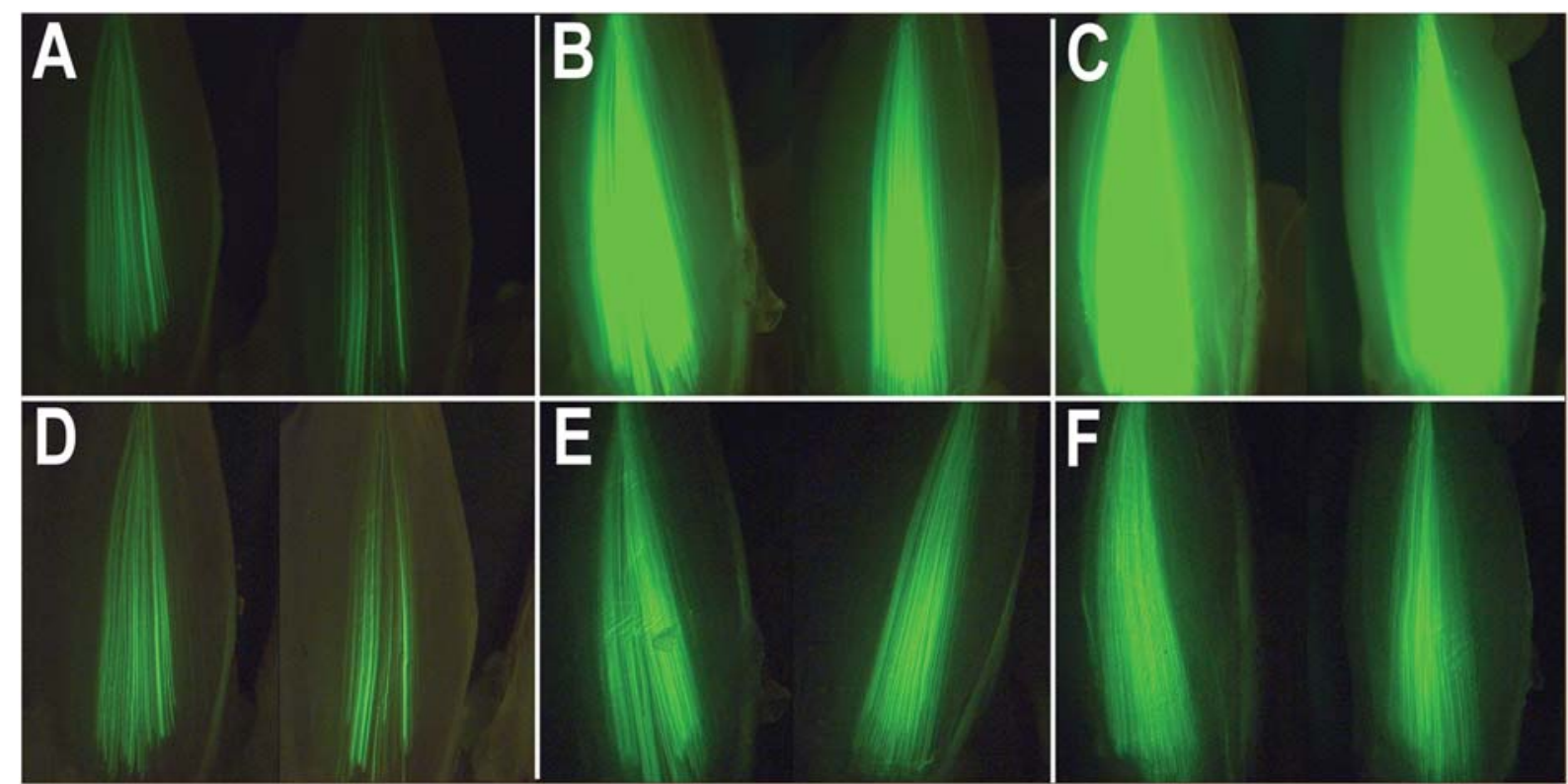

FIG. 5. GFP expression in tibialis cranialis muscles after DNA electrotransfer by combinations of one $\mathrm{HV}$ pulse $(800 \mathrm{~V} / \mathrm{cm}, 100$ $\mu \mathrm{sec}$ ) and one LV pulse of $400 \mathrm{msec}$ and either 60, 80, or $100 \mathrm{~V} / \mathrm{cm}$. (A and D) LV of $60 \mathrm{~V} / \mathrm{cm}$; (B and E) LV of $80 \mathrm{~V} / \mathrm{cm}$; (C and F) LV of $100 \mathrm{~V} / \mathrm{cm}$. (A-C) Camera exposure time was fixed at $100 \mathrm{msec}$. (D) Exposure times were $243 \mathrm{msec}$ (left muscle) and 392 msec (right muscle). (E) Exposure times were $36 \mathrm{msec}$ (left muscle) and $55 \mathrm{msec}$ (right muscle). (F) Exposure time was $23 \mathrm{msec}$ for both muscles. Representative images of four muscles treated under each of the experimental conditions are shown.

be shown by taking into account the in vitro results of Zaharoff and Yuan (2004) on the mobility in agarose gels of DNA molecules exposed to pulse durations similar to those of the LV pulses described here. The agarose gels used by these authors are supposed to mimic interstitial barriers in biological tissues. They found that the dependence of plasmid electromobility on pulse duration was not linear and displayed a sigmoid shape: at shorter durations electromobility is low, whereas with longer durations it increases, reaching a plateau at $50 \mathrm{msec}$ in $1 \%$ agarose gels, and at higher pulse duration $(80-100 \mathrm{msec})$ in more concentrated gels (2-3\% agarose). Indeed, for a plasmid to move through the narrow passages in agarose gels, random coiled DNA should elongate in the direction of motion and shrunk in the perpendicular direction (Zaharoff and Yuan, 2004). Then, if a long LV pulse is substituted by multiple shorter LV pulses, separated by $1 \mathrm{sec}$, the elongated plasmid relaxes between the pulses. The consecutive LV pulses must again align the plasmid along the direction of the electric field. This alignment takes time and therefore electrophoresis of the plasmid is not as efficient as in the case of a single but long pulse. Moreover, because tissue structure is much more complex than an agarose gel, electromobility of the plasmid should still be more dependent on pulse duration.

Plasmid DNA electrophoresis in tissues is further supported by another study by Zaharoff et al. (2002) showing that in tumors, electric pulses similar to the LV pulses used here can actually produce the electrophoretic migration of DNA over distances of about $1 \mu \mathrm{m}$. Thus the LV pulses should be sufficient to bring the DNA from the bulk of the injected liquid into close contact with the permeabilized plasma membrane of the muscle cell and/or to contribute to translocation of the DNA through the permeabilized membrane. In addition to pure electrophoretic effects, it cannot be excluded that LV pulses might increase the myofiber perme- abilization created by the HV pulse (in particular for the longest and more intense LV pulses). This might contribute to enhanced electrotransfer efficacy. However, the results of Fig. 1 clearly show that the level of cell permeabilization is not of primary importance. Moreover, the results of Fig. 2 strongly argue in favor of the hypothesis that efficacy of gene electrotransfer is governed mainly by the electrophoretic forces of the LV pulses.

When we tested various LV pulse field strengths (Fig. 3), the same low level of luciferase expression was achieved with $\mathrm{LV}$ pulses up to $40 \mathrm{~V} / \mathrm{cm}$ than with the $\mathrm{HV}$ pulse alone (equivalent to the delivery of an $\mathrm{LV}$ at $0 \mathrm{~V} / \mathrm{cm}$ ). Low transfection efficiency using LV pulses of 20 or $40 \mathrm{~V} / \mathrm{cm}$ may be explained by the absence of an "electrophoretic field" in the muscle, caused by the voltage drop across the skin. Indeed, even if skin is electropermeabilized, it still remains highly nonconductive, provoking a substantial voltage drop (data not shown). Thus, on the one hand, it is possible that with LVs of 20 or $40 \mathrm{~V} / \mathrm{cm}$ the electrophoretic force in the muscle tissue was negligible and, on the other hand, that an increase in LV pulse amplitude from 60 to $100 \mathrm{~V} / \mathrm{cm}$ resulted in a progressive increase in luciferase expression (Fig. 3), according to the basic rules of electrophoresis. Pulses of $60 \mathrm{~V} / \mathrm{cm}$ and 20 to $83 \mathrm{msec}$ in duration do not contribute to muscle fiber permeabilization (Gehl and Mir, 1999; Bureau et al., 2000), even if they are delivered after one $100-\mu \mathrm{sec}$ HV (Mir et al., in preparation). Thus, using pulses of $60 \mathrm{~V} / \mathrm{cm}$, only the electrophoretic effects of such pulses should be observed. Interestingly, the data reported in Fig. 4 demonstrate that long-enough pulses $(400 \mathrm{msec})$ at 60 $\mathrm{V} / \mathrm{cm}$ result in luciferase expression similar to that achieved with the $80-\mathrm{V} / \mathrm{cm}$ pulses, and that much longer pulses $(800$ $\mathrm{msec})$ result in still higher luciferase expression. So, the decreased electrotransfer efficacy with the $60-\mathrm{V} / \mathrm{cm}$ LVs (at a du- 
ration of $100 \mathrm{msec}$ ) can be fully compensated by an increase in pulse duration, which is in clear agreement with electrophoresis principles.

As expected from the results with the luciferase gene, the increase in field strength of the LVs resulted in an increase in GFP fluorescence (Fig. 5). Qualitative and quantitative data clearly showed that this increase in fluorescence resulted from the greater fluorescence of each fiber; the volume of tissue affected by the electrotransfer remained the same. This is in agreement with the previous assignment of roles of the HV and LV pulses. The experiments reported in Fig. 5D-F show that the same volume of tissue was affected by the DNA electrotransfer, which was expected because the same HV pulse was used under the three experimental conditions. Within the volume of tissue affected by the HV pulse, the fluorescence of the individual fibers increased with an increase in the strength of the LVs from 60 to $100 \mathrm{~V} / \mathrm{cm}$ (Fig. 5A-C). The increase in electrophoretic effect should bring more plasmid molecules in contact with the electropermeabilized membrane and, consequently, more plasmid molecules should be able to cross the plasma membrane, resulting in the observed enhancement of the efficacy of DNA electrotransfer.

The electrophoretic effect of LV pulses may contribute to increased transfection efficacy in several ways. First, they may induce sufficient DNA electrophoresis to bring plasmid DNA from the bulk of the interstitium into contact with permeabilized membranes. Second, when the plasmid molecules are already in contact with permeabilized membranes, the electrophoretic force of LV pulses may facilitate translocation of the plasmid molecules into the cells.

In conclusion, consistent with previous in vitro reports and our previous in vivo work, the present study confirms that efficient electrogene transfer is based on at least two distinct effects exerted by the electric pulses: cell permeabilization and DNA electrophoresis. The results of the current study highlight the importance of in vivo DNA electrophoresis in electrotransfer efficacy. We demonstrate that, provided some muscle permeabilization is achieved by the prerequisite $\mathrm{HV}$ pulse, DNA electrotransfer efficiency is governed by the electrophoretic effect of the LV pulse(s). These results provide new avenues for further optimization of in vivo electrogene therapy.

\section{ACKNOWLEDGMENTS}

This research has been supported through various grants from the CNRS; the Institut Gustave-Roussy; Aventis-Gencell; the EU Commission (Project QLK3-1999-00484 within the fifth FP); the Ministry of Education, Science, and Sports (MESS) of the Republic of Slovenia; and the Lithuanian State Science and Studies Foundation (K-C 17/2). Exchanges have been possible also thanks to the bilateral program of scientific, technological, and cultural cooperation between the CNRS (Project 5386) and MESS (Proteus program). The authors acknowledge Tamsin Wright Carpenter for linguistic revisions of this paper and also thank the staff of the Service Commun d'Expérimentation Animale of the IGR for animal maintenance. During part of this work, S. $\breve{S}$. was the recipient of a research grant from Aventis to L.M.M.

\section{REFERENCES}

AIHARA, H., and MIYAZAKI, J. (1998). Gene transfer into muscle by electroporation in vivo. Nat. Biotechnol. 16, 867-870.

ANDRÉ, F., and MIR, L.M. (2004). DNA electrotransfer: Its principles and an updated review of its therapeutic applications. Gene Ther. 11(Suppl. 1), S33-S42.

AUSUBEL, F.M., BRENT, R., KINGSTON, R.E., MOORE, D., SEIDMAN, J.G., SMITH, J.A., and STRUHL, K. (1994). Current Protocols in Molecular Biology. (John Wiley \& Sons, New York).

BETTAN, M., EMMANUEL, F., DARTEIL, R., CAILLAUD, J.M., SOUBRIER, F., DELAERE, P., BRANELEC, D., MAHFOUDI, A., DUVERGER, N., and SCHERMAN, D. (2000). High-level protein secretion into blood circulation after electric pulse-mediated gene transfer into skeletal muscle. Mol. Ther. 2, 204-210.

BUREAU, M.F., GEHL, J., DELEUZE, V., MIR, L.M., and SCHERMAN, D. (2000). Importance of association between permeabilization and electrophoretic forces for intramuscular DNA electrotransfer. Biochim. Biophys. Acta 1474, 353-359.

GEHL, J., and MIR, L.M. (1999). Determination of optimal parameters for in vivo gene transfer by electroporation, using a rapid in vivo test for cell permeabilization. Biochem. Biophys. Res. Commun. 261, 377-380.

GEHL, J., SKOVSGAARD, T., and MIR, L.M. (1998). Enhancement of cytotoxicity by electropermeabilization: An improved method for screening drugs. Anticancer Drugs 9, 319-325.

GEHL, J., SØRENSEN, T.H., NIELSEN, K., RASKMARK, P., NIELSEN, S.L., SKOVSGAARD, T., and MIR, L.M. (1999). In vivo electroporation of skeletal muscle: Threshold, efficacy and relation to electric field distribution. Biochim. Biophys. Acta 1428, 233-240.

GLASS, L.F., JAROSZESKI, M., GILBERT, R., REINTGEN, D.S., and HELLER, R. (1997). Intralesional bleomycin-mediated electrochemotherapy in 20 patients with basal cell carcinoma. J. Am. Acad. Dermatol. 37, 596-599.

GOLZIO, M., TEISSIE, J., and ROLS, M.P. (2002). Direct visualization at the single-cell level of electrically mediated gene delivery. Proc. Natl. Acad. Sci. U.S.A. 99, 1292-1297.

HELLER, L., JAROSZESKI, M.J., COPPOLA, D., POTTINGER, C., GILBERT, R., and HELLER, R. (2000). Electrically mediated plasmid DNA delivery to hepatocellular carcinomas in vivo. Gene Ther. 7, 826-829.

HELLER, L.C., and COPPOLA, D. (2002). Electrically mediated delivery of vector plasmid DNA elicits an antitumor effect. Gene Ther. 9, 1321-1325.

HELLER, R., JAROSZESKI, M., ATKIN, A., MORADPOUR, D., GILBERT, R., WANDS, J., and NICOLAU, C. (1996). In vivo gene electroinjection and expression in rat liver. FEBS Lett. 389, 225-228.

KLENCHIN, V.A., SUKHAREV, S.I., SEROV, S.M., CHERNOMORDIK, L.V., and CHIZMADZHEV, Y. (1991). Electrically induced DNA uptake by cells is a fast process involving DNA electrophoresis. Biophys. J. 60, 804-811.

MATSUMOTO, T., KOMORI, K., SHOJI, T., KUMA, S., KUME, M., YAMAOKA, T., MORI, E., FURUYAMA, T., YONEMITSU, Y., and SUGIMACHI, K. (2001). Successful and optimized in vivo gene transfer to rabbit carotid artery mediated by electronic pulse. Gene Ther. 8, 1174-1179.

MIKLAVČIČ, D., S̆EMROV, D., MEKID, H., and MIR, L.M. (2000). A validated model of in vivo electric field distribution in tissues for electrochemotherapy and for DNA electrotransfer for gene therapy. Biochim. Biophys. Acta 1523, 73-83.

MIR, L.M., BELEHRADEK, M., DOMENGE, C., ORLOWSKI, S., PODDEVIN, B., BELEHRADEK, J., SCHWAAB, G., LUBOINSKI, B., and PAOLETTI, C. (1991a). [Electrochemotherapy, a new antitumor treatment: first clinical trial]. C. R. Acad. Sci. III 313, 613-618.

MIR, L.M., ORLOWSKI, S., BELEHRADEK, J., and PAOLETTI, C. (1991b). Electrochemotherapy potentiation of antitumour effect of bleomycin by local electric pulses. Eur. J. Cancer 27, 68-72. 
MIR, L.M., BUREAU, M.F., RANGARA, R., SCHWARTZ, B., and SCHERMAN, D. (1998a). Long-term, high level in vivo gene expression after electric pulse-mediated gene transfer into skeletal muscle. C. R. Acad. Sci. III 321, 893-899.

MIR, L.M., GLASS, L.F., SERSA, G., TEISSIE, J., DOMENGE, C., MIKLAVČIČ, D., JAROSZESKI, M.J., ORLOWSKI, S., REINTGEN, D.S., RUDOLF, Z., BELEHRADEK, M., GILBERT, R., ROLS, M.P., BELEHRADEK, J., BACHAUD, J.M., DECONTI, R., STABUC, B., CEMAZAR, M., CONINX, P., and HELLER, R. (1998b). Effective treatment of cutaneous and subcutaneous malignant tumours by electrochemotherapy. Br. J. Cancer 77, 2336-2342.

MIR, L.M., BUREAU, M.F., GEHL, J., RANGARA, R., ROUY, D., CAILLAUD, J.M., DELAERE, P., BRANELLEC, D., SCHWARTZ, B., and SCHERMAN, D. (1999). High-efficiency gene transfer into skeletal muscle mediated by electric pulses. Proc. Natl. Acad. Sci. U.S.A. 96, 4262-4267.

MURAMATSU, T., SHIBATA, O., RYOKI, S., OHMORI, Y., and OKUMURA, J. (1997). Foreign gene expression in the mouse testis by localized in vivo gene transfer. Biochem. Biophys. Res. Commun. 233, 45-49.

MURAMATSU, T., NAKAMURA, A., and PARK, H.M. (1998). In vivo electroporation: A powerful and convenient means of nonviral gene transfer to tissues of living animals [review]. Int. J. Mol. Med. 1, 55-62.

NEUMANN, E., KAKORIN, S., TSONEVA, I., NIKOLOVA, B., and TOMOV, T. (1996). Calcium-mediated DNA adsorption to yeast cells and kinetics of cell transformation by electroporation. Biophys. J. 71, 868-877.

PODDEVIN, B., ORLOWSKI, S., BELEHRADEK, J., and MIR, L.M. (1991). Very high cytotoxicity of bleomycin introduced into the cytosol of cells in culture. Biochem. Pharmacol. 42(Suppl.), S67-S75.

RODRIGUEZ, C., BARROSO, B., ALMANZA, E., CRISTOBAL, M., and GONZALEZ, R. (2002). Electrochemotherapy in primary and metastatic skin tumors: Phase II trial using intralesional bleomycin. Arch. Med. Res. 32, 273-276.

ROLS, M.P., DELTEIL, C., GOLZIO, M., DUMOND, P., CROS, S., and TEISSIE, J. (1998). In vivo electrically mediated protein and gene transfer in murine melanoma. Nat. Biotechnol. 16, 168-171.

S̆ATKAUSKAS, S., BUREAU, M.F., MAHFOUDI, A., and MIR, L.M. (2001). Slow accumulation of plasmid in muscle cells: Supporting evidence for a mechanism of DNA uptake by receptor-mediated endocytosis. Mol. Ther. 4, 317-323.

S̆ATKAUSKAS, S., BUREAU, M.F., PUC, M., MAHFOUDI, A., SCHERMAN, D., MIKLAVČIČ, D., and MIR, L.M. (2002). Mechanisms of in vivo DNA electrotransfer: respective contributions of cell electropermeabilization and DNA electrophoresis. Mol. Ther. 5, $133-140$.
SERSA, G., STABUC, B., CEMAZAR, M., JANCAR, B., MIKLAVČIČ, D., and RUDOLF, Z. (1998). Electrochemotherapy with cisplatin: Potentiation of local cisplatin antitumour effectiveness by application of electric pulses in cancer patients. Eur. J. Cancer 34, 1213-1218.

SOUBRIER, F., CAMERON, B., MANSE, B., SOMARRIBA, S., DUBERTRET, C., JASLIN, G., JUNG, G., CAER, C.L., DANG, D., MOUVAULT, J.M., SCHERMAN, D., MAYAUX, J.F., and CROUZET, J. (1999). pCOR: A new design of plasmid vectors for nonviral gene therapy. Gene Ther. 6, 1482-1488.

SUKHAREV, S.I., KLENCHIN, V.A., SEROV, S.M., CHERNOMORDIK, L.V., and CHIZMADZHEV, Y. (1992). Electroporation and electrophoretic DNA transfer into cells: The effect of DNA interaction with electropores. Biophys. J. 63, 1320-1327.

SUZUKI, T., SHIN, B.C., FUJIKURA, K., MATSUZAKI, T., and TAKATA, K. (1998). Direct gene transfer into rat liver cells by in vivo electroporation. FEBS Lett. 425, 436-440.

TITOMIROV, A.V., SUKHAREV, S., and KISTANOVA, E. (1991). In vivo electroporation and stable transformation of skin cells of newborn mice by plasmid DNA. Biochim. Biophys. Acta 1088, 131-134.

WELLS, J.M., LI, L.H., SEN, A., JAHREIS, G.P., and HUI, S.W. (2000). Electroporation-enhanced gene delivery in mammary tumors. Gene Ther. 7, 541-547.

ZAHAROFF, D.A., and YUAN, F. (2004). Effects of pulse strength and pulse duration on in vitro DNA electromobility. Bioelectrochemistry 62, 37-45.

ZAHAROFF, D.A., BARR, R.C., LI, C.Y., and YUAN, F. (2002). Electromobility of plasmid DNA in tumor tissues during electric fieldmediated gene delivery. Gene Ther. 9, 1286-1290.

ZHANG, L., LI, L., HOFFMANN, G.A., and HOFFMAN, R.M. (1996). Depth-targeted efficient gene delivery and expression in the skin by pulsed electric fields: an approach to gene therapy of skin aging and other diseases. Biochem. Biophys. Res. Commun. 220, 633-636.

Address reprint requests to: Dr. Lluis M. Mir UMR 8121 CNRS-Institut Gustave Roussy 39 Rue C. Desmoulins F-94805 Villejuif Cédex, France

E-mail: luismir@igr.fr

Received for publication February 20, 2005; accepted after revision July 28, 2005.

Published online: September 23, 2005. 